DOI: 10.1515/ausfm-2018-0009

\title{
Approaches to Studying Intermediality in Contemporary Cinema
}

\author{
Ágnes Pethő \\ Sapientia Hungarian University of Transylvania (Cluj-Napoca, Romania) \\ E-mail: petho.agnes@kv.sapientia.ro
}

\begin{abstract}
The article attempts a brief overview and evaluation of the main theoretical approaches that have emerged in the study of cinematic intermediality in the last decades since intermediality has become an established research term in media studies. It distinguishes three major paradigms in theorizing intermedia phenomena and outlines some of the directions of change in the intermedial strategies of recent films. It identifies in contemporary cinema a tendency to add new dimensions to the relations of in-betweenness regarding both the connection of cinema to reality and its inter-art entanglements. Finally, the article describes a new type of intermediality, which integrates elements of trans-textuality, creating a format of expanded cinema within cinema. This strategy is presented in the context of Eastern European cinema through a short case study of Cristi Puiu's film, Sieranevada (2016). ${ }^{1}$
\end{abstract}

Keywords: theory of intermediality, in-betweenness, Raymond Bellour's double helix, Cristi Puiu, Sieranevada.

\section{Paths in the Theoretical Jungle}

Several decades after the idea of intermediality came into the spotlight within communication and media studies, and at a time when studies of cinematic intermediality have gained new momentum through the vigorous research activity within several academic projects at universities around the world, the variety in approaches and a burgeoning scholarly literature interwoven with far too many metaphors may still puzzle anyone trying to get acquainted with the field. I would like to address, therefore, headlong this heterogeneity of the discourse on intermediality and review its major directions of thought, briefly

1 This work was supported by a grant of the Romanian Ministry of National Education, CNCS UEFISCDI, project number PN-III-P4-ID-PCE-2016-0418. 
assessing their implications and productivity. In the process of mapping the theoretical field, I have tentatively identified three major paradigms (conceived around the ideas of: a) media borders, b) in-betweenness, c) connecting the real and the intermedial), which I will summarize below. These paradigms may be seen as partially overlapping, nevertheless, they all have their divergent vantage points in perception and methodology.

\section{a) Blurring the Borders}

The "crossing of media borders" is one of the most persistent metaphors in the study of intermediality, one that is at the centre of perhaps the most clearly identifiable paradigms in the study of intermediality. Irina Rajewsky considers it as "a founding category" (2010, 52, cf. also 2002, 11-15). In the same vein, Lars Elleström defines intermediality as "a result of constructed media borders being trespassed," and postulates that even though "there are no media borders given by nature [...] we need borders to talk about intermediality" $(2010,27)$. By now, talking of "blurred borders" and "media trespasses" have not only entered the vocabulary of intermedial analyses but they have also become somewhat blurry figures of speech themselves, frequently divorced from a precise theoretical background. Nevertheless, we should keep in mind that the rhetoric based on the metaphor of media borders originates in a particular perspective that defines a very important and broad avenue in intermediality studies.

The borders in question are admittedly constructed (historically, cognitively and conventionally) and perceivable on different levels as differences that frame each medium coming into contact with another. Theoretical writings based on such "border-talks" conceive intermediality as a relationship between media and are concerned with typologies of modalities and operations that can identify what happens to media (more precisely, to media forms or media characteristics) in an inter-media relationship. Media differences constitutive of their "borders" as well as similarities which enable their interpenetration are equally important. Broadly speaking, and disregarding the terminological debates, according to such typologies, in an intermedial border crossing: a) media are fused, combined, integrated to form a complex multimedia or hybrid entity, ${ }^{2}$ b) media (forms, characteristics, products) are represented, referenced by other media, or c)

2 This is the case of the so-called synthetic intermediality in Jens Schröter's view (cf. 2011, 2012). It is also one of Elleström's main categories for intermedial relations (2010). 
characteristics (which are either specific to one medium or not ${ }^{3}$ ) are transposed, trans-mediated, ${ }^{4}$ trans-semioticised (Gaudreault and Marion 2004), transformed or re-mediated. The pursuit of refining such typologies makes use of diverse theories of communication but it is ultimately rooted in semiotics and aspires to produce definitions of categories that can function as a conceptual framework for identifying intermedial relations across different media. Much of this type of scholarship deliberately aims to develop a meta-theory, working on definitions of what intermediality is and elaborating a universal grammar of intermediality of sorts applicable to the analysis of a variety of media phenomena. As such, it is conceived primarily as a branch of media studies which it attempts to "fine tune" and amend. ${ }^{5}$ On the one hand, looking further back for connections, we may see a great affinity with the tradition of aesthetics dealing with the idea of the "sister arts," the rivalry and limitations of specific art forms. ${ }^{6}$ On the other hand, this avenue connects surprisingly easily to the relatively newer area of transmedia, cross-media or media convergence studies of the digital age, despite their completely opposite premise (i.e. instead of the emphasis on borders that separate and distinguish individual media, and across which "trespasses" are made, these studies presuppose that such borders have already collapsed in a so called post-media age). Although they deal with practices making use of the merging and interconnectedness of formerly distinct media technologies and media forms within a digital environment, and a "convergence culture" where old and new media meet in a "flow of content across multiple media platforms" (Jenkins 2006, 2), the focus is similarly on categories and operations in a perspective that is essentially the flip side of intermedial "border-talks."”

3 Schröter describes this latter instance as formal (or transmedial) intermediality, "a concept based on formal structures not 'specific' to one medium but found in different media" (2011).

4 In Elleström's definition: "transmediation is repeated mediation by another type of medium (exemplified by adaptation)" (2014, 11).

5 See in this respect Elleström's criticism of Jay David Bolter and Richard Grusin's seminal book, Remediation: Understanding New Media (1999), which, he writes: "is full of relevant observations but severely lacks in-depth theoretical discussions on the nature and different forms of 'remediation.' The authors' notions of media and remediation are acutely vague. In a way, my own study is an attempt to develop more finely tuned notions that rival the allembracing concept of remediation of Bolter and Grusin" (2014, 7-8).

6 I.e. as manifested in the Renaissance concept of paragone, in Gotthold Ephraim Lessing's famous Laocoön essay (1767), or the Wagnerian ideal of the Gesamtkunstwerk (1849).

7 Jean-Marc Larue's short article (2014) also supports this idea of connecting these theories by presenting remediation, hypermediation, media convergence, and transmediality as ideas that emerged in logical succession. 


\section{b) Being In-Between}

The alternative to the paradigm based on the border metaphor (and its research goals of identifying a limited set of well-defined media characteristics and operations describing their trespassing "movements" or mergers) can be seen in theoretical pursuits that shift the emphasis towards the idea of some kind of in-betweenness. At first sight this might seem related to the former metaphorical image of media boundaries, and indeed the concept does occur in writings belonging to the first type mentioned here and which briefly acknowledge the existence of liminal/ contact/border zones when discussing intermedial occurrences (e.g. Rajewsky $2010,59)$. Still, there is also a vast and far more heterogeneous area of a variety of theoretical approaches which converge on the notion of in-betwenness based on different philosophical perspectives and which have usually very little to do with the semiotics-based scholarship of intermediality outlined before.

Bernd Herzogenrath observes, quoting the Fluxus artist Dick Higgins's words who coined the term "intermedia" in 1966, that "intermedium" is not only the "uncharted land that lies between" $(2012,2)$ in the sense that it comprises "the links (and cross-breeds) between various art forms" but also in the sense of connecting "various disciplines with which we talk about these media. [...] Intermedia[lity] thus can very literally be described as between the between" $(2012,2)$. While the border metaphor prevails in the attempts to forge a solid theoretical framework for a single discipline of intermedial studies dealing with all media forms, the metaphor of in-betweenness not only suggests an impossibility of pinning down the boundaries, a state of instability, of being in the "blur" (rather than the act of blurring formerly distinct entities), but it is also a key notion which opens the way to the absorption of different methodologies as well as a multiplication of perspectives regarding the phenomena of intermediality.

In terms of theorizing, so far, the application of post-structuralist philosophies has been the most productive in the exploration and "opening up" of the inbetween. One could not even attempt a comprehensive survey here, suffice it to say that thoughts of Gilles Deleuze, Michel Foucault, Jean-François Lyotard have influenced important researches into intermediality from this perspective. Based on Deleuze, for example, Herzogenrath redefines the main issues in this way: "rhizomatic interconnections among the various media are what constitute the field of intermedia[lity]. Intermedia[lity] is thus the 'media-version' of the plane of immanence, of that fractal surface - which is not to say that first there are different media, and then there is intermedia[lity]: this rhizomatic 
intermedia[lity] is the quasi-ontological plane underlying all media, out of which the specific media that we know percolate, so to speak" $(2012,3)$. Intermediality has often been articulated through Foucault's notion of heterotopia (e.g. in Borer, Schellow, Schimmel, Wodianka, eds. 2013) as an in-betweenness of space, time and media forms. ${ }^{8}$ Then again, in-betweenness has also been theorized not as a metaphorical or unidentifiable place, a state, but in terms of Lyotard's notion of the figural (with strong links to phenomenology and psychoanalysis). To quote Lyotard himself, the figural arises as an "interworld" in the text, something "a linguistic space cannot incorporate without being shaken, an exteriority it cannot interiorize as signification" but remains "steadfastly within the sensory" and "every form of discourse exhausts itself before exhausting it" $(2011,7)$. In the book Reading the Figural (2001), David Rodowick argues that the figural can be seen "as a transversal concept" $(2001,32)$ that can demolish the illusory divide of the textual versus visual from both sides, and reverses Lyotard's perspective (who starts from observing the text) by identifying the work of the figural within the media hybridity of cinema, where its effect is to challenge "the self-coherence of the visual" $(2001,33)$. It is Joachim Paech who explicitly applies the notion to cinematic intermediality, defining it "as a perceivable figure of media difference which disturbs the order of the discourse" $(2011,73)$ as a radical heterogeneity.

Viewing intermediality in terms of the figural is therefore the perfect model of in-betweenness, for instead of delimiting media boundaries, it reveals their deep imbrication, it connects the discursive with the non-discursive, universally recognizable structures with whatever cannot be fitted into categories. Moreover, if we remember Lyotard's poetic description linking the figural with beauty, the sublime, and what he calls the untamed "silence of art" standing "as plasticity and desire, a curved expanse against invariability" (2011, 7), we can see that the figural not only brings a welcome "leap into the void" (Rodowick 2001, 4) of inbetweenness, but it may highlight what is singular in each instance of intermediality, much in the spirit of Dick Higgins's original idea that intermedial works are "not governed by rules; each work determines its own medium and form according to its needs" $(2001,50)$. As such, this line of thought, influenced by diverse strands of so-called post-structuralist philosophies, leads the way in the exploration of intermediality not as an abstract set of relationships (i.e. a kind of grammar), but as an ever-changing aesthetic configuration, and a sensuously perceivable excess. ${ }^{9}$

8 See more on intermediality conceived in terms of heterotopia in Pethő (2011, 42-43).

9 Henk Oosterling, for example, speaks of a "sensible" intermediality in which "the sensible, as a reflective sensibility, balances between presence and absence: going back and forth from one medium to the other," and considers it as "a movement in which positions are articulated in the 
While the previous avenue of intermedial studies is heading in one specific direction (i.e. the general theory of intermediality applicable for each separate media), this type of scholarship, which has gained much traction in film studies, has successfully decentred the field both with an emphasis on dealing with specific instances of intermediality through analyses of works, auteurs or stylistic trends in diachronic or synchronic cross-section, and with freely adopting and combining concepts not only from media studies or philosophy but from a wide range of disciplines (including film theory, art history, aesthetics, psychology, anthropology, etc.). The direction set by philosophies of in-betweenness was also recently reinforced by studies focusing on the "liminal" in cultural and postcolonial studies, which extended the idea of the "blurry area" of in-betweenness to interpreting historical, cultural, social and psychological phenomena.

\section{c) Remapping Intermediality and Rethinking In-Betweenness}

Moving beyond the widespread influence of post-structuralism, the most intriguing new perspectives for thinking about intermediality in cinema have been brought by the works of recent philosophers and film theorists like Alain Badiou, Jacques Rancière, Giorgio Agamben or Raymond Bellour, who have explicitly written about cinema and offered new vantage points for interpreting its hybridity. Although these theoretical approaches are far from being similar in many respects, there are a few aspects that loosely connect them: for example, without mentioning the term intermediality, they all implicitly point toward expanding the area to be considered in intermediality studies beyond media. They suggest diverse possibilities to radically rethink, this time not the metaphor of media borders but another core assumption of intermediality, namely that this is something that happens between media, that its relevance extends solely to relations between media.

Alain Badiou interprets the designation of "the seventh art" not as indicative of the position of cinema among the arts but of the way it is constituted: it is not simply another art added to the succession of previously existing ones, but as he famously says, it is the "plus-one" of the arts in the sense that "it operates on the other arts, using them as its starting point, in a movement that subtracts them from themselves" $(2013,89)$. Badiou writes: "all the arts flow through cinema. [...] Cinema uses and magnifies them, according them a distinctive emotional power. There's a power of revelation of the arts, a power of subjugation of the arts in cinema that truly makes it the seventh art" $(2013,7)$. 
And although the metaphor of the "breached borders" resurfaces in his arguments, he also makes it clear that any "movement from one art to another" is a false one, a subtraction, "an allusive quotation of the other arts," through which we have a fleeting passage of an idea, like a "visitation," cinema working essentially as an "art of memory," for, as Badiou notes, "what I will have seen or heard lingers on to the very extent that it passes" $(2013,88)$. Reviving André Bazin's metaphor of "impurity," he considers cinema to be "an impure art" (Badiou 2013, 93), that is, "a knot that ties together" the movements in which cinema not only "wrests the[se] arts away from themselves" $(2013,92)$, but also connects to the domain of non-art ${ }^{10}$ and becomes contaminated ${ }^{11}$ by it. Accordingly, it is not the image that identifies cinema but this kind of "impurity," and cinema as artistic practice can be conceived as a never completed "process of purification of its own immanent non-artistic character" $(2013,139)$. Through this key notion Badiou weaves together the inter-art relations in film with a set of other relationships outside the arts which are closely linked to them.

We see a similar gesture of extending and remapping the area where cinema (and thinking about cinema) operates on the principle of in-betweenness in Jacques Rancière's recent writings (2014). Only instead of Badiou's vision of binding together the divergent aspects of cinema, Rancière "pulls" them apart, by emphasizing the "gaps" or "intervals" (les écarts) of cinema. Like Badiou, Rancière, too, speaks of the "impurity" of cinema and highlights the revelatory experience of cinephilia for the perception of the medium's essential hybridity in which the discovery of a "closer and less obvious linkage between the types of art" may occur at the same time with the experience of "the emotions of the narrative" or "the splendour that the most commonplace objects could acquire on a lighted screen in a dark auditorium" $(2014,3)$. Questioning the very unity of the art, he states, "cinema exists only as a set of irreducible gaps between things that have the same name without being members of a single body" $(2014,5)$. "The gaps of cinema are the results of cinema being other to itself - this internal heterogeneity producing extensions or relations with literature, politics, and other art forms. Gaps and extensions make cinema overflow itself. These 'gaps'

10 Badiou considers in this respect the connections between the art of cinema and cinema as entertainment, a product of the movie industry, as a medium "steeped into the infinite of the real" $(2013,18)$.

11 Perhaps Badiou can also be credited with bringing into vogue a series of biological metaphors like cross-pollination, contamination, fertilization, etc. that have pervaded the recent texts written on intermediality. 
are precisely what make it excessive in the sense of extending the questions and experiences it produces to other 'non-cinematic' fields" (Rancière 2012). ${ }^{12}$

Giorgio Agamben joins the rank of the contemporary philosophers who venture into these 'non-cinematic' fields not only through considering film as a "nexus of relationships between differently constituted objects and practices" (Harbord 2016, 217), and as the champion of what Janet Harbord, the author of a recent monograph on his work calls "ex-centric cinema" (2016), driven by a veritable fascination with what is external to it, but most of all, through dislodging the image from the centre of discourse on cinema altogether and replacing it with "gesture." Thus, for Agamben, cinema re-enacts the tale of the living statue: "the mythical rigidity of the image has been broken" as the cinematic world unfolds a "dream of a gesture" $(2000,55)$, he writes. "Properly speaking, there are no images but only gestures" $(2000,55)$ in cinema. Gesture itself is articulated in multiple ways as an agent of in-betweenness, between dance and image, language and pure spectacle, the body as an "exhibition of mediality," of "being-in-a-medium" $(2000,57)$ and its obliteration by the alienating machinic gaze of the cinematic apparatus, and ultimately as the "intersection between life and art" (2000, 79).

This recovery of the non-cinematic and cinema's various relationships with the real within thinking about cinematic hybridity in the writings of these theorists not only institutes a new kind of "border-talk," this time between art and nonart, the real and the intermedial, but it is also marked by a strong emphasis on performativity (on what intermediality does). Unlike the metaphors of "media trespasses" of the first paradigm, which define what intermediality is in an abstract fashion, these relationships are considered here literally as action and interaction, as relations of power and conflict with the possibility of unearthing tensions that go beyond the realm of media. As Badiou once said, cinema is not "a peaceful art."13 A great contribution to this line of thought is Lúcia Nagib’s elaboration on the "politics of impurity" (2014), which draws inspiration from Bazin's visionary ideas, and connects intermediality conceived in terms of impurity with Rancière's notion of dissensus, "which establishes new relations between reality and appearance, the individual and the collective, multiplying

12 Endnote to Rancière's article in NECSUS (2012) written by Sudeep Dasgupta in consultation with Rancière.

13 Badiou speaks of cinema as "the visibility of the conflict between art and non-art in the contemporary world" in a public lecture delivered in 2015 at the University of New South Wales, Sidney, available on YouTube https://www.youtube.com/watch? $v=$ Arwso3fy50M\&t=2320s. Last accessed 17. 07. 2018. 
the possibilities of the film medium in a polemical way, while challenging its own limits and the power of representation" $(2014,37)$.

The disruptive way in which intermedial relations are enacted in cinema are perhaps most explicitly spelled out by Raymond Bellour in the essays collected in his two books $(1990,1999)$ written about all kinds of mixtures between photo, cinema, video, painting, literature, and digital media. His key concepts of "entre-images" or "images-in-between" unfold a vision of in-betweenness in which forms are "hollowed out from within" $(2012,21)$ or "irrigated" by the new forces that surround it $(2012,21)$, there are fissures, interventions, intrusions, collusions and corruptions. Speaking about an "explosion" of cinema into other forms of moving images, Bellour shifts the discourse on in-betweenness from "media" as a system of signs (similarly to Badiou or Rancière's inspiration drawn from their own cinephilia) to the more palpable, real-life framework of the "dispositifs" in which they are experienced, and where, again, he sees inbetweenness in terms of multiplication, tension and as the title of his more recent book indicates, The Battle of the Dispositifs (2012b). At this point I will conclude this brief (and unavoidably incomplete) overview of some of the central questions regarding the state of the art in what can be defined as a broadly inclusive area of intermediality studies. What is important to note regarding these three major paradigms (1. based on the idea of "media trespasses;" 2. contact-zones mapped through post-structuralist philosophies; 3. rethinking in-betweenness between art and non-art, the real and the intermedial) is that despite partial overlaps (less between the first and the other two, more between the second and third), there is no unified framework here. If we try to assess the research output in these areas, we can see that, notwithstanding all the rigour of scientific accuracy and a declared purpose of elaborating adequate tools for the analyses of a wide range of intermedial phenomena, the studies based on "trans-semiotic border-talks" which make use of a media studies framework without any hybridization with other fields of theoretical inquiry have so far proved to be rather self-enclosed. They remain within the bounds of abstract meta-theory, the most important achievements in this paradigm are the carefully elaborated definitions of what intermediality is and the identification of its subcategories. (Whereas analyses which apply these well-defined categories are often satisfied with pigeonholing instances of intermediality and thus prove to be derivative and less productive in their results.) Researches that adhere to the second and third paradigms conceive intermediality in terms of multiple in-betweennesses, and open up new avenues by acknowledging the need for multiplication of perspectives as well. They 
consist of case studies and theoretical investigations which seem only loosely associated with the kind of intermediality studies (rooted in semiotics and media studies) practiced in the first paradigm. Their most productive lines of inquiries seek out new, interdisciplinary vantage points also at the level of methodologies (studying less the concept of intermediality per se, and focusing more on the contingencies, phenomenologies, philosophies and specific historical, poetical manifestations of intermediality).

In the following subchapter, based on ideas gleaned from the theoretical writings that redefine intermedial in-betweenness in the third paradigm drawn up earlier, I will present how a recent Eastern European film can help us to explore the changing strategies of intermediality in contemporary cinema, and even to sketch the contours of an emerging new type of intermedial and inter-art relationship.

\section{Changing Strategies of In-Betweenness: the Double Helix of Intermediality}

In order to highlight these new strategies, Raymond Bellour's metaphor of the double helix (1996) seems to be a good starting point. Bellour borrowed the notion of the double helix from molecular biology in an article written originally for the catalogue of the landmark exhibition entitled Passages of the Image (Passages de l'image, organized by the Pompidou Centre in Paris, in 1990, and which was the first of its kind to bring together photography, cinema, video and digital image installations in an intermedial dialogue). Through the complex model of the double helix Bellour further unpacks his concept of the images-in-between. Images in the digital age, he writes, are not only ubiquitous but ever harder to define as things-in-themselves; we experience them more in terms of "passages of the image," where the ambiguous preposition "of" includes not only the sense of "in-between" the images but also the viewers passing "in front of" images and a more obscure connection to "what is missing from the image" or to "what contains it" (1996, 174), a passage, as the motto chosen by Bellour from Henri Michaux's poem indicates, "from one mist to one flesh" $(1996,173)$. Furthermore, moving images combine embodied and disembodied experience, reality and artificiality, sensations and codes through the double helix structure intertwining two forms of analogy: the photographic reproduction of the real (i.e. the analogy based on natural vision), and the mechanical reproduction of movement (i.e. the way the cinematic apparatus creates its own visible world) $(1996,180)$. Although, in principle, this structure applies to all visual media, its complexity is enhanced 
in cinema because "a pattern of possibilities is established, formed by the overlappings and passages that are capable of operating (technically, logically, and historically) between the different arts" (Bellour 1996, 180).

Extending the metaphor to another level, and taking into account the import of all the other recent theorizations which introduce the real into the discourse of intermediality, we may perhaps consider the inter-art and inter-media connections and analogies on the one hand, and the power of the cinematic image to resemble, represent and to rely on various "passageways" to material reality (from its production to its interpretation), on the other, as two sets of relations (comprising the domains of art and non-art) joined in a similar double helix. On both sides there are further interrelationships (or as Badiou would say, "impurities") at play, yet they are constantly interlocked. Intermediality operates in this way like the DNA of cinema, connecting the old with the new: "inherited" forms, patterns, conventions, with technological and aesthetic innovations and mutations. It weaves the fabric of cinema through its virtually infinite connections between the arts and an inalienable bond with perceptions of the real, anchored in bodily sensations.

But one should not insist too much on the metaphor in itself, its relevance is merely to suggest that this conjunction is where important changes can be seen regarding the intermedial poetics of contemporary cinema (besides the obvious area marked by CGI technology, where reality, artificiality and the passages between the arts can converge or diverge along a wide spectrum). There is a growing strategy to add new dimensions to the relations of in-betweenness in a way that ultimately produces a new type of intermediality emerging in contemporary cinema. This new type can be added to the other basic "templates" (see Pethő 2011, 95-179) that generate a more or less emphatic sense of intermediality within a film also based on inter-media/inter-art associations correlated with our sensations of the real (i.e. a sensual mode that brings forth impressions of other arts through a synesthetic experience of the world; and a structural mode that unravels the world into pieces and layers of media forms and representations). In these days of media convergence and multiplied real-intermedial and interart contact-zones, we can also distinguish an expansive mode that excessively stretches and "skews" the cinematic form in the direction of other arts and media, at times adding further trans-media extensions to a film, while on the other hand, many times, in parallel with the newest trends of site-specificity and the preference for more personal or immersive forms in the arts, it anchors the cinematic world further into a specific historical, cultural context. To co-opt 
Rancière's terminology, in such an expansive mode, cinema may "overflow itself" (2012) both through the "gaps" between media (as it displays a chameleon-like ability to change its appearance to resemble the other arts and to be incorporated, remediated by other arts), as well as the "gaps" between the medium and physical reality (the connection to which is reinforced on many levels and in many ways). One such strategy relies on creating "contaminated" forms (to apply Badiou's term), on creating a format of "expanded cinema" ${ }^{14}$ within cinema, in which there is a mutual infiltration between the arts and media, between art and nonart, through a unique expansion or folding of one form over the other. We can see in this way, for example, films which we experience as if they were conceived as prolonged video installations (often also reconfigured as such, relocated into the realm of installation art, with fragments extracted and displayed on multiple screens adapted to specific venues, e.g. Lech Majewski's The Mill and the Cross, $2011^{15}$ ), video blogs (e.g. Sally Potter's Rage, 2009), recorded theatre and/or multimedia performances (e.g. Peter Greenaway's 2007 Nightwatching, alongside his other, VJ performance-like films), and so on. As these examples suggest, this expansion may employ multiple strategies, but in what follows, I would like to present a more subtle and manifold "contamination" and "expansion" of cinema along both axes of the double helix through a closer look at the Romanian film Sieranevada, directed by Cristi Puiu in 2016.

The film, inspired by the events surrounding the death of the director's father, is about a family reunion on the occasion of the Orthodox ritual for remembering the dead forty days after the funeral. The large family is making preparations for the religious ceremony without much piety but with plenty of bickering. A great feast is prepared yet this is somewhat absurdly constantly delayed. According to the intentions of the director, the film presents the family gathering through the imagined perspective of the dead man, yet this point of view is never actually

14 The term "expanded cinema" was applied, in the mid 1960s, to avant-garde artworks that used moving images (e.g. video, multimedia performance) and sought to rethink the way moving images can be produced, exhibited and experienced beyond the framework of traditional cinema. The meaning of the term has also undergone some expansion, from a specific art movement that can be seen as a branch of so-called structuralist film that included elements of live performance and experiments with projections in unconventional locations, forms and multiple screens, to encompassing all kinds of new media art practices making use of moving images. The idea of viewing new media as an expansion of cinema beyond its traditional boundaries originates in Gene Youngblood's famous book with the same title (1970), which described the implications of new image-making technologies emerging after cinema.

15 In Julian Rosefeldt's Manifesto (2015) we have an example for the reverse procedure, in which installation art expands into cinema, i.e. scenes filmed for a multi-screen installation have been edited into a full-length film. 
articulated in the film, and it is only the spectator who is in the position of watching through the mobile eyes of the camera, moving closely around the people as an invisible guest. With more than a dozen characters paraded in front of us, the film paints a contemporary fresco of "the human comedy" of contemporary Romanian society. In accordance with Agamben's iconoclastic rethinking of cinema, the absence of genuine mourning is filled with a rich choreography of everyday gestures in a truly gestural cinema that renounces classical dramaturgy for fluctuations in tensions, endlessly repeated acts of comings and goings from one room to another, doors opening and closing, people entangled in petty arguments, banal conversations peppered with political conspiracy theories, the venting of frustrations and bitter recriminations within an overcrowded apartment in Bucharest. [Figs. 1-3.]

Stretched over 173 minutes, the film challenges the attention span of the viewer, who gets immersed in this way not so much in a story, but in a world, in a sensuous universe of voices, gesticulating bodies moving in and out of the dark hallway and the cluttered rooms. Gesturality prevails over the image also in these richly decorated, box-like spaces, in which the paintings, mirrors, superimposed with photographs and holy icons all point to people having placed them there. Even the first images in which we may be struck by the pictorial quality of the composition, the scene is pervaded by the gestures of human intervention in the world, with the colourful graffiti in the background and the cars jostling around in the crowded street. And although the film may be seen also as a hilariously deadpan, postcommunist variation on thematic or stylistic elements borrowed from the cinema of Luis Buñuel, John Cassavetes or Eric Rohmer, its strength resides in its quasi real-time format, making the viewer part of an experience resembling something in-between reality TV and the newest vogue of site-specific theatre, in which plays are staged within the confined space of people's homes, actors mingling with spectators, and making them literally "go through" the performance, thus "bleeding" art (or artifice) directly into the perception of reality and vice versa. ${ }^{16}$

In such a heavy contamination of cinema with theatricality on the one hand, and everydayness on the other, it is surprising to see how more sophisticated art references also pop up (something we are accustomed to see in Eastern European films with a more aestheticized style). Mantegna's Dead Christ or Michelangelo's Pietá is evoked in two scenes by the postures of the protagonists. [Figs. 4-5.]

16 Another recent Eastern European film to apply such a strategy is It's Not the Time of My Life (Ernelláék Farkaséknál), made in the same year as Sieranveda, in 2016. The Hungarian director, Szabolcs Hajdu actually adapted his own play performed originally as a site-specific theatre show into a so-called no-budget film made with the collaboration of his own family and students. 
In both cases, what we have is not a clear reference, but only a hint, a fleeting impression that lingers over the image, or "passes through" exemplifying what Badiou describes as the "the visitation of the idea in cinema" $(2013,123)$, like the passage of "grace" coming through the transparent veil of the images. While similar images that we encounter throughout global commercial cinema and popular art are used as fairly straightforward devices meant to add a degree of sophistication to the image, the examples in Eastern European cinema, as several previous studies have shown, ${ }^{17}$ are usually much more ambivalent or layered. In this case, they appear side by side with references to Western politics and culture (for example, in the form of the argument over the Disney costume of the little girl) and within a much more complex framework, in which the idea that comes along with the Dead Christ or the Pietá may be perceived both in terms of irony (mocking the chaotic gathering and the lack of cultured sophistication) and in terms of a genuine yearning for authentic mourning as well as for a connection to (European) high art. With regards to art references, Mircea Valeriu Deaca (2016) notes that although everything in the film revolves around a ceremonial feast, the most obvious art reference, the one to Da Vinci's Last Supper is missing, and he interprets this absence as a gesture of denying the bearded protagonist, Lary, the central role and the association with Christ. However, we do find a reference to the Last Supper, only it comes not in the film, but in the poster made for the film, in the arrangement of the family chatting and smiling at the dinner table (quite inappropriately for a funeral reception). [Fig. 6.] The image devised for the international distribution takes into account the expectations of the market regarding the specific Eastern European "brand," in which irony, ambivalence, sophisticated allusion is something to be expected.

We should be aware, nevertheless, that Cristi Puiu himself created another poster for the film, which was used for its domestic advertising, and which shows the fog-infused outskirts of Bucharest with a string of typically dreary blocks of flats lined up under the horizon and a frozen lake in the foreground with a flock of black crows gathered around the patch of thin ice in the middle. [Fig. 7.] Designed by the director-author, this photo-pictorial poster art would have been in itself a meaningful trans-media extension of the work had it not opened the way towards another set of artworks altogether. And this brings us to the other possible strategy of this type of expansive intermediality.

In this mode we may see connections established across interrelated works conceived in multiple art forms in which one becomes the extension of the

17 The interpretation of art references is one of the key issues in the study of the intermediality of Eastern European cinema, see among others: Pethő (2014), Király (2016), Pieldner (2016). 
other. This mode integrates elements of intermediality with trans-textuality (e.g. in the present case, the actor Mimi Brănescu, who was used deliberately as a connection to The Death of Mr. Lazarescu [Moartea domnului Lăzărescu], 2005) and transmediality (meaning that different interconnected works constitute parts of the same universe). This extension happens most of the times in the direction of installation art. Several examples from contemporary cinema may come to mind: from the installations of Pedro Costa to those of Apichatpong Weerasethakul. Or we may remember that Béla Tarr also broke his earlier promise not to make any more films, in a way, by exhibiting a newly shot short film within an art installation expanding the universe of his films at the Eye Film Museum in Amsterdam in 2017. ${ }^{18}$ In the case of Puiu, the extension was made in the direction of photography. Searching for an adequate image for the poster art, the director took hundreds of photographs at the outskirts of Bucharest, a selection of which was exhibited at the Baril Art Gallery in Cluj in June 2017 (and later in the same year in the Art Museum in Arad). At this exhibition, the whole collection was made available to the public in the form of a photo album printed in one copy, displayed in the same space together with a selection of the photos hung on the wall and a booklet containing an in-depth interview with the director, transforming the whole exhibition into a complex multimedia installation. The photos extend the universe we saw in the film by moving away, paradoxically, from the fictional story into the "real world," from the beehive of blocks of flats where Puiu staged the highly realistic family squabbles in his film towards a highly aestheticized, peaceful landscape covered with snow. The particular image chosen for the poster [Fig. 7] shows the frozen artificial lake created by a dam on the Dâmbovița river in the 1980s, also flooding in the process the site of an old cemetery. Conscious of its history, Puiu, elevates the foggy image into an expression of his own diffuse feelings of melancholy or anxiety overlaying the historical memory of the place. Other compositions also frame the cemetery next to the grey blocks of flats with its old headstones buried under snow or single out the lonely elements of the landscape, industrial buildings looming in the distance, tracks in the snow, some reduced to a few graphic elements only, like brushstrokes on a canvas. For the viewers of the exhibition, the series of elegantly minimalist, almost monochrome compositions framed in white, displayed on the white walls of the art gallery set up a perceivable aesthetic distance, cleanse the

18 The title of the exhibition was Till the End of the World, and it ran from 21 January to 7 May 2017. See: https://www.eyefilm.nl/en/exhibition/b\%C3\%A9la-tarr-\%E2\%80\%93-till-the-endof-the-world. Last accessed 17. 07. 2018. 
universe of the film contaminated by the vulgarity of everydayness and introduce a visible gap not only between cinema and photography but also between art and non-art, reality and its sophisticated mediation. [Figs. 8-11.] Across these gaps the connections and reversals unfold an expansive artistic vision that ultimately challenges our perception of the world, and effectively reframes the real from multiple perspectives. Thus, in a chiastic structure, everydayness conveyed through the immersive realism of the film (ordinary happenings, real-time quarrels which we perceive more like "life" than art), i.e. non-art is shown as art, as a fictional story, while in the stylish, minimalistic photographs hung in the art gallery it is a highly sophisticated, visibly constructed $\operatorname{art}^{19}$ that shows us real locations. A fictional family network unravels in front of us, up close and seemingly personal in the film, while what is actually deeply personal for the director ${ }^{20}$ is conveyed through the impersonal, wide-angle landscape photography bordering on abstraction. ${ }^{21}$

This multiplicity of perspectives and manners of presentation (fictional, realistic, ordinary, sophisticated, metaphorical, artificial, abstract, personal, etc.) appears in an unusual form already in the title of the film (Sieranevada), written in a provocatively fine print and with a deliberate misspelling of the geographical name, Sierra Nevada. On a literal level, the word contains a puzzling and ambiguous misreference to a snowy mountain range either in Europe (Spain) or in America. The snowy images associated with the name may perhaps be loosely linked to the photographs taken in winter around the outskirts of Bucharest, but they have absolutely no connection with the film, in which the name is never mentioned (correctly or incorrectly) and only disorients the viewer who searches for hidden references. According to several press conference interviews with Puiu, he chose an absolutely arbitrary title to mock the practice of attaching labels to everything, and partly, also in protest against foreign distribution practices that usually change the title of films, thus making sure it will stay the same. In this way, however, without becoming a metaphor in the film, the title can be perceived as a subversive gesture of defiance and dissent added to the film, multiplying references in the sense Rancière conceives dissensus "as the

19 The photos were later further framed as "art" being published alongside the film in an expensive, collector's edition Blu-ray box-set with the author's unique handwritten quotations from the film and signature.

20 The pictures showing his own daughter and the drawing made by her included in the selection of exhibited photographs all reinforce this personal nature of the photographs.

21 We may go further and see also a bit of a site-specific irony in the fact that the immaculate, white box of the art gallery exhibiting these photos in Cluj is actually inside a shabby building of an old, abandoned factory. 
presence of two worlds in one" $(2010,37)$, "the demonstration (manifestation) of a gap in the sensible itself" $(2010,38)$. The mistaken spelling, the meaning that may take us to two different places, the many possible associations, and finally the impossibility to connect any of them to the diegetic world intrigue the viewer, and introduce just the kind of "multiplicity of folds and gaps in the fabric of common experience that change the cartography of the perceptible, the thinkable and the feasible" that Rancière speaks about $(2009,72)$ when describing the "political" effect of an aesthetic experience.

Evoking a well-known name in the title yet making it strange on so many levels, reinforces in a condensed linguistic form the same characteristics that we saw in the art references connecting to and disconnecting the film from a conventional frame of reference. It demonstrates how intermedial strategies can emerge as interfaces between East and West, and as such, become inscriptions and articulations of a desire for cultural (re)connections, while, on the other hand, they can also stage an effective dissensus regarding the standardization of images (or words, concepts, etc.) within a globalized world. They employ the overflowing excess of the double helix of intermediality for enmeshing current general trends of aesthetic practices (e.g. "contaminating" cinema with forms of reality TV or site-specific theatre, engaging the complex relationship of interrelated artworks conceived in different media) as well as universally recognisable iconography with images enrooted within the intranslatability of specific, local anxieties and realities. Such examples as Sieranevada, Cristi Puiu's intertwined project of film and photography, present new and complex configurations of in-betweenness which challenge us to explore their uncharted implications by searching for theoretical tools that can reveal the depths and layers of intermedial strategies in contemporary cinema.

\section{References}

Agamben, Giorgio. 2000. Means without End. Notes on Politics. Minneapolis, London: University of Minnesota Press.

Badiou, Alain. 2013 [2010]. Cinema. Cambridge: Polity Press.

Bellour, Raymond. 1996. The Double Helix. In Electronic Culture. Technology and Visual Culture, ed. Timothy Druckrey, 173-199. New York: Aperture.

Bellour, Raymond. 1999. L'entre images2: mots, images [Between-the-Images 2. Words, Images]. Paris: P.O.L.

Bellour, Raymond. 2012a [1990]. Between-the-Images. Zürich: JRP/Ringier \& Les Presses du Réel. 
Bellour, Raymond. 2012b. La Querelle des dispositifs. Cinéma - installations, expositions [The Quarrel of the Dispositifs]. Paris: P.O.L.

Bolter, Jay David and Richard Grusin. 1999. Remediation: Understanding New Media, Cambridge, MA, London: The MIT Press.

Borer, Nadja, Constanze Schellow, Nina Schimmel and Bettina Wodianka, eds. 2013. Heterotopien: Perspektiven der intermedialen Ästhetik [Heterotopias. Perspectives of Intermedial Aesthetics]. Bielefeld: Transkript Verlag.

Deaca, Mircea Valeriu. 2016. Sieranevada sau trecerea de la lumină la întuneric [Sieranevada, or the Crossing from Light to Darkness]. Cultura vol. 12 (556): 26-28.

Elleström, Lars. 2010. The Modalities of Media: A Model for Understanding Intermedial Relations. In Media Borders, Multimodality and Intermediality, ed. Lars Elleström, 11-48. London, New York: Palgrave Macmillan.

Elleström, Lars. 2014. Media Transformation:The TransferofMedia Characteristics Among Media. London, New York: Palgrave Macmillan.

Gaudreault, André and Philippe Marion. 2007. Transécriture and Narrative Mediatics. The Stakes of Intermediality. In A Companion to Literature and Film, eds. Robert Stam and Alessandra Raengo, 58-70. Malden MA, Oxford UK: Blackwell Publishing.

Herzogenrath, Bernd, ed. 2012. Travels in Intermedia[lity]: Reblurring the Boundaries. Hanover, New Hampshire: Dartmouth College Press.

Harbord, Janet. 2016. Ex-Centric Cinema. Giorgio Agamben and Film-Archeology. New York [etc.]: Bloomsbury Academic.

Higgins, Dick. 2001 [1965]. Intermedia. Leonardo vol. 34, no. 1: 49-54.

Jenkins, Henry. 2006. Convergence Culture. Where Old and New Media Collide. New York, London: New York University Press.

Király, Hajnal. 2016. Looking West: Understanding Socio-Political Allegories and Art References in Contemporary Romanian Cinema. Acta Universitatis Sapientiae: Film and Media Studies vol. 12: 67-87.

Larrue, Jean-Marc. 2014. The "In-Between" of What? Intermedial Perspectives on the Concept of Borders/Boundaries. Digital Studies/Le champ numérique vol. 5. http://www.digitalstudies.org/ojs/index.php/digital_studies/article/ view/308/454. Last accessed 17. 07. 2018.

Lessing, Gotthold Ephraim. 1984 [1767]. Laocoön: An Essay on the Limits of Painting and Poetry. Baltimore MD and London: Johns Hopkins University Press. Lyotard, Jean-Francois. 2011 [1971]. Discours, Figure. Minneapolis, London: University of Minnesota Press. 
Nagib, Lúcia. 2014. The Politics of Impurity. In Impure Cinema. Intermedial and Intercultural Approaches to Film, eds. Nagib, Lúcia and Anne Jerslev, 21-39. London, New York: I.B. Tauris.

Oosterling, Henk. 2003. Sens(a)ble Intermediality and Interesse. Towards the Ontology of the In-Between. Intermédialitiés no. 1 (Printemps): 29-46.

Paech, Joachim. 2011. Das Medium formuliert, die Form figuriert [The Medium is Formulated, the Form is Figured]. In Äesthetische Erfahrung der Intermedialität. Zum Transfer künstlerischer Avantgarden und 'illegitimer' Kunst im Zeitalter von Massenkommunikation und Internet [Aesthetic Experience of Intermediality. On the Transfer of Artistic Avant-garde and "Illegitimate" Art in the Age of Mass Communication and the Internet], ed. Thomas Becker, 57-75. Bielefeld: Transkript Verlag.

Pethő, Ágnes. 2011. Cinema and Intermediality. The Passion for the In-Between. Newcastle upon Tyne: Cambridge Scholars Publishing.

Pethő, Ágnes. 2014. The Tableau Vivant as a "Figure of Return” in Contemporary East European Cinema. Acta Universitatis Sapientiae: Film and Media Studies vol. 9: 51-76.

Pieldner, Judit. 2016. Magic Realism, Minimalist Realism and the Figuration of the Tableau in Contemporary Hungarian and Romanian Cinema. Acta Universitatis Sapientiae: Film and Media Studies vol. 12: 87-115.

Rajewsky, Irina O. 2002. Intermedialität. Tübingen and Basel: Francke.

Rajewsky, Irina O. 2010. Border Talks: The Problematic Status of Media Borders in the Current Debate about Intermediality. In Media Borders, Multimodality and Intermediality, ed. Lars Elleström, 51-69. London, New York: Palgrave Macmillan.

Rancière, Jacques. 2009. The Emancipated Spectator. New York, London: Verso. Rancière, Jacques. 2010. Dissensus. On Politics and Aesthetics. New York: Continuum.

Rancière, Jacques. 2012. The Gaps of Cinema. Necsus. http://www.necsus-ejms. org/the-gaps-of-cinema-by-jacques-ranciere/. Last accessed 17. 07. 2018.

Rancière, Jacques. 2014. The Intervals of Cinema. London, New York: Verso.

Rodowick, David N. 2001. Reading the Figural, or, Philosophy after the New Media. Durham \& London: Duke University Press.

Schröter, Jens. 2011. Discourses and Models of Intermediality. CLCWeb: Comparative Literature and Culture vol. 13, no. 3. http://docs.lib.purdue.edu/ clcweb/vol13/iss3/3. Last accessed 17. 07. 2018. 
Schröter, Jens. 2012. Four Models of Intermediality. In Travels in Intermedia[lity]: Reblurring the Boundaries, ed. Bernd Herzogenrath, 15-37. Hanover, New Hampshire: Dartmouth College Press.

Wagner, Richard. 1993 [1849]. The Art-Work of the Future and Other Works. Lincoln and London: University of Nebraska Press.

Youngblood, Gene. 1970. Expanded Cinema. New York: P. Dutton \& Co.

\section{List of Figures}

Figures 1-3. People coming and going, arguing in an overcrowded apartment in Sieranevada (2016).
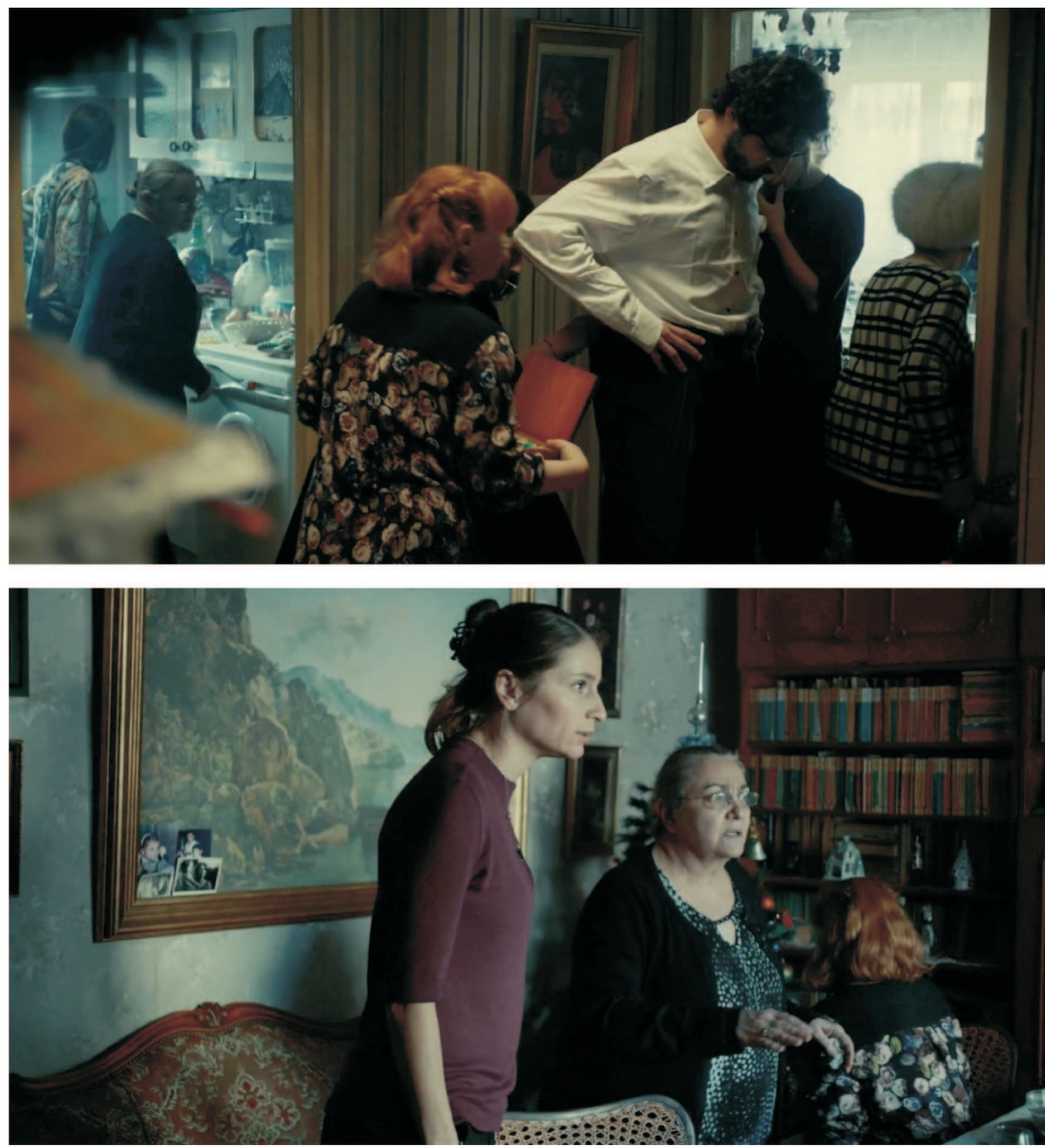


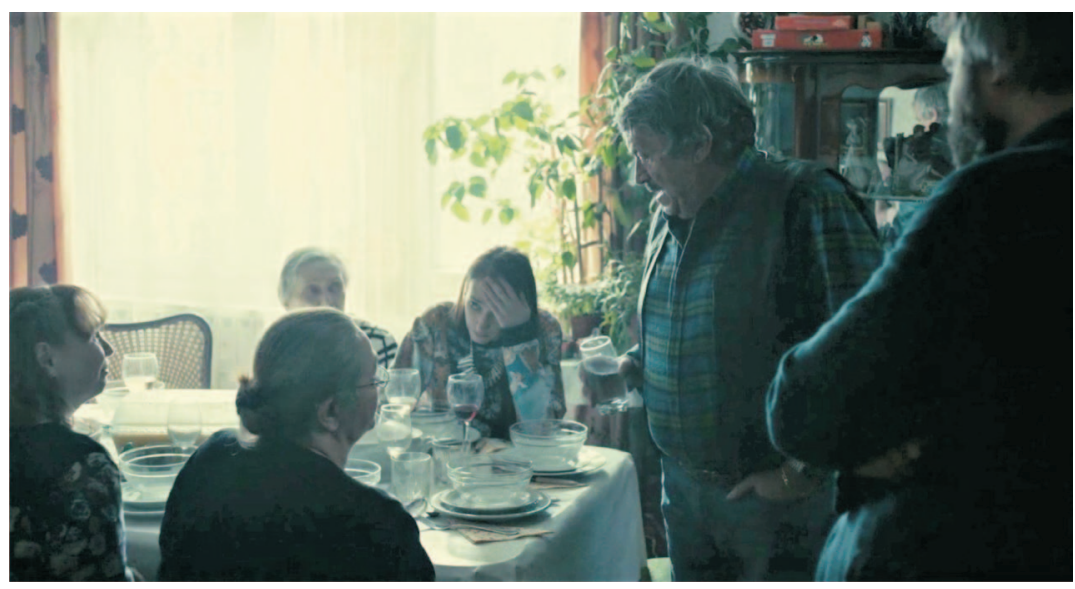

Figures 4-5. The postures of the protagonists faintly recalling Andrea Mantegna's painting of Dead Christ and Michelangelo's Pietá.
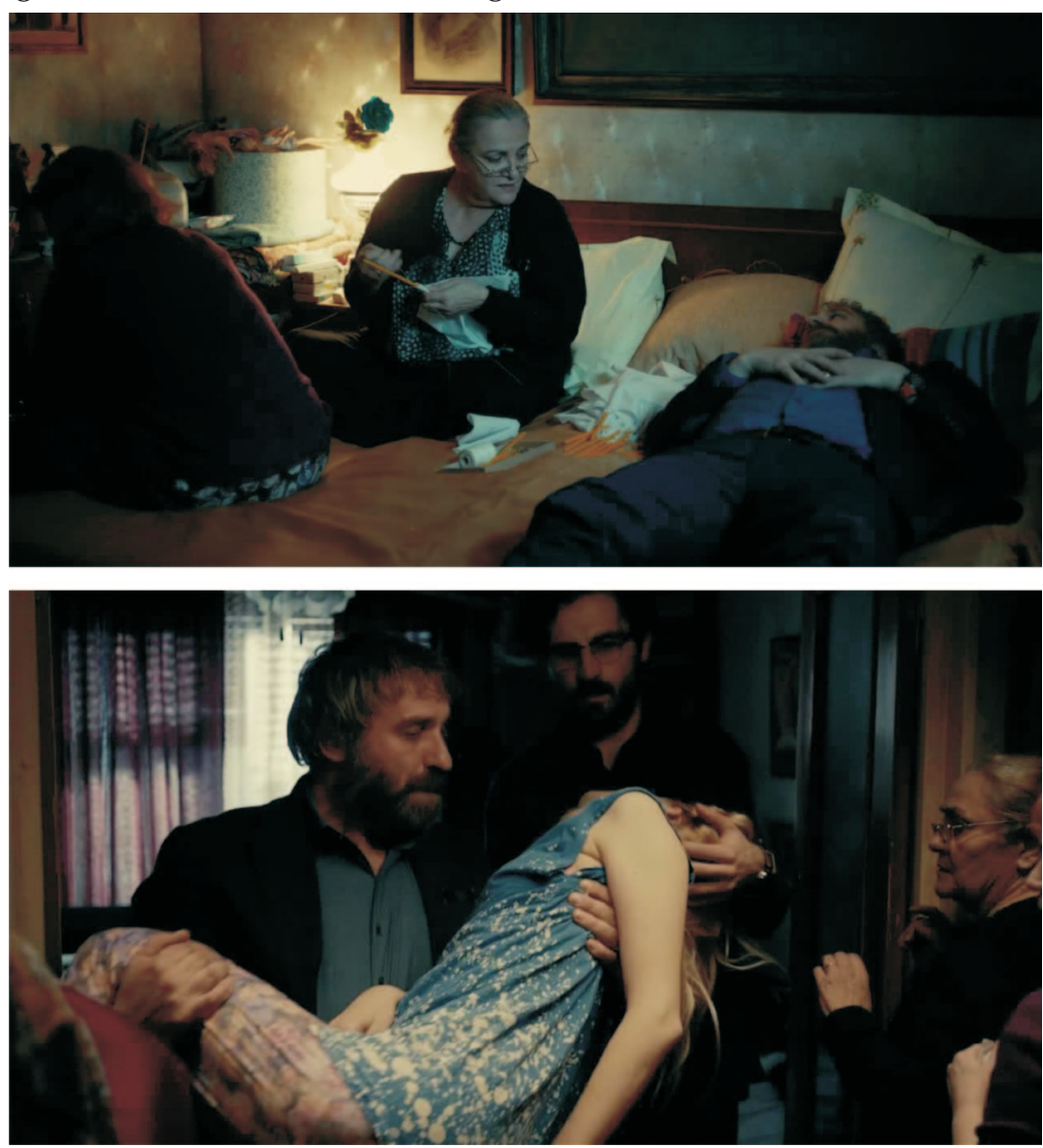
Figures 6-7. The two posters of Sieranevada: one made for the international distribution of the film, reminiscent of Leonardo Da Vinci's Last Supper, the other, using a photograph taken by Cristi Puiu himself at the outskirts of Bucharest, designed for its domestic spectators.
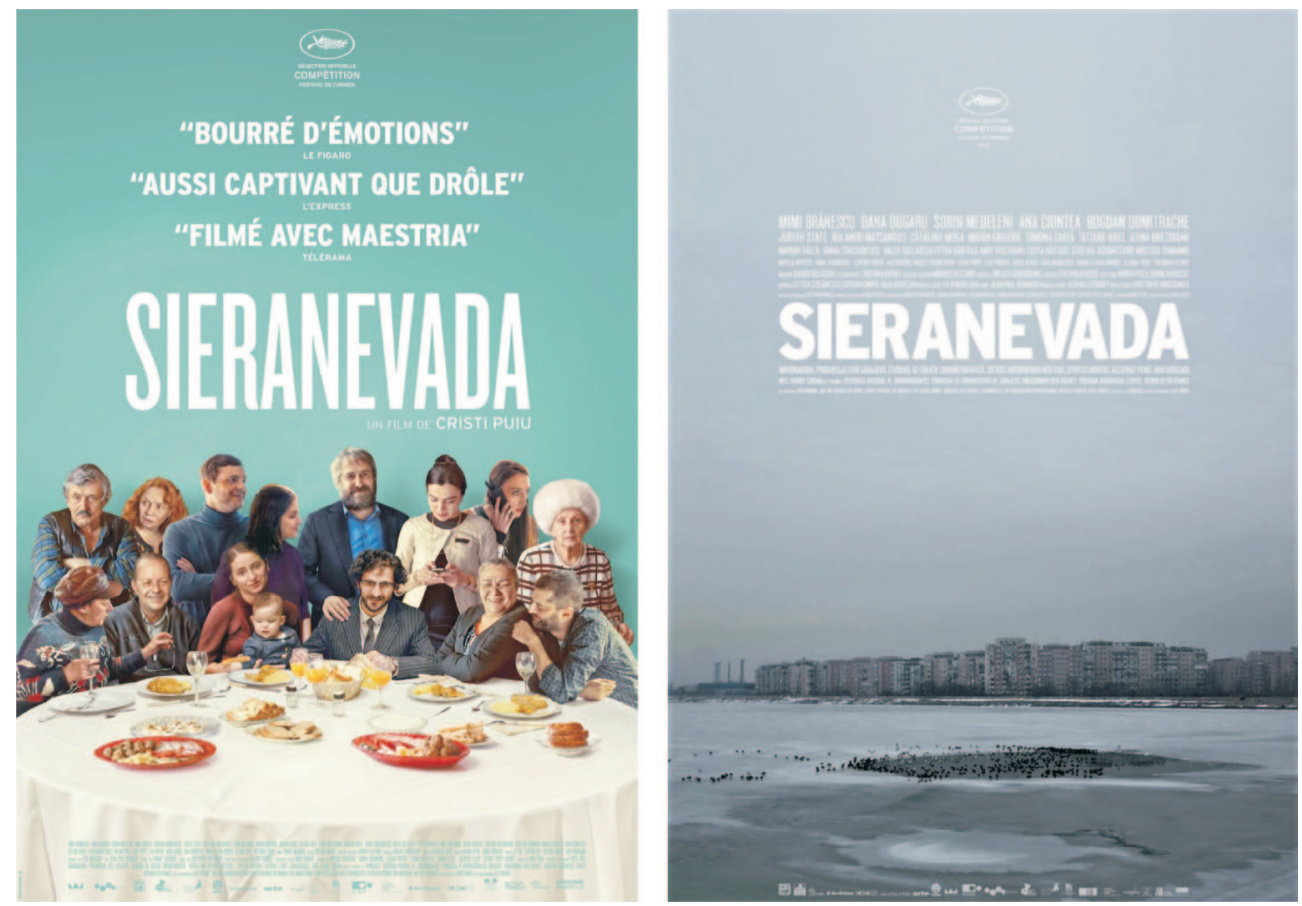

Figures 8-11. Photos shown in the exhibition with the same title, Sieranevada (insallation view, photographed by the author).

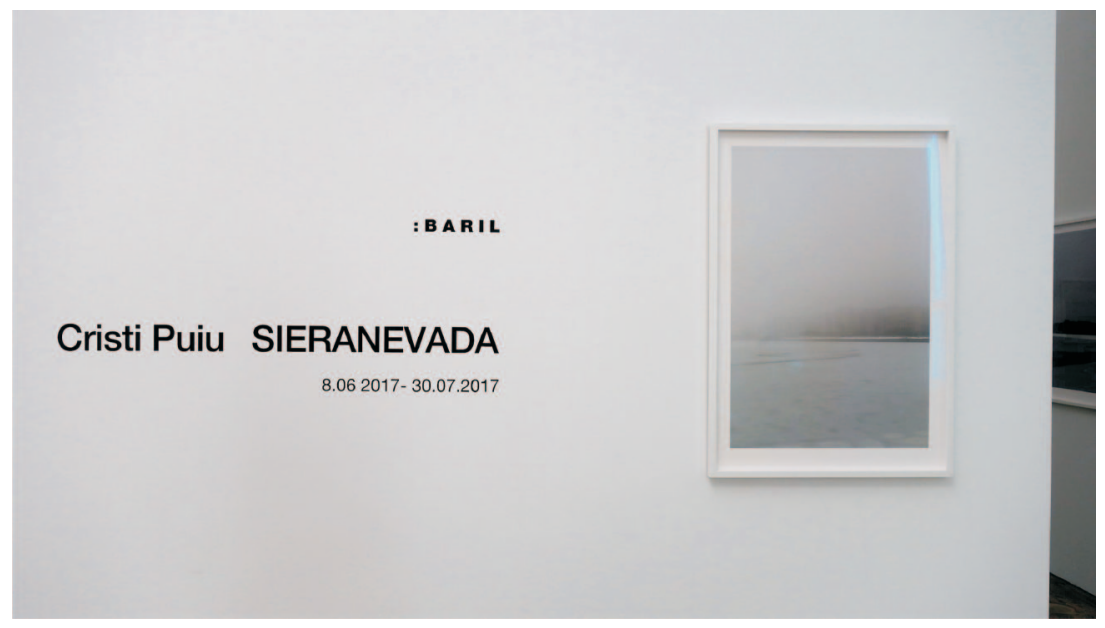



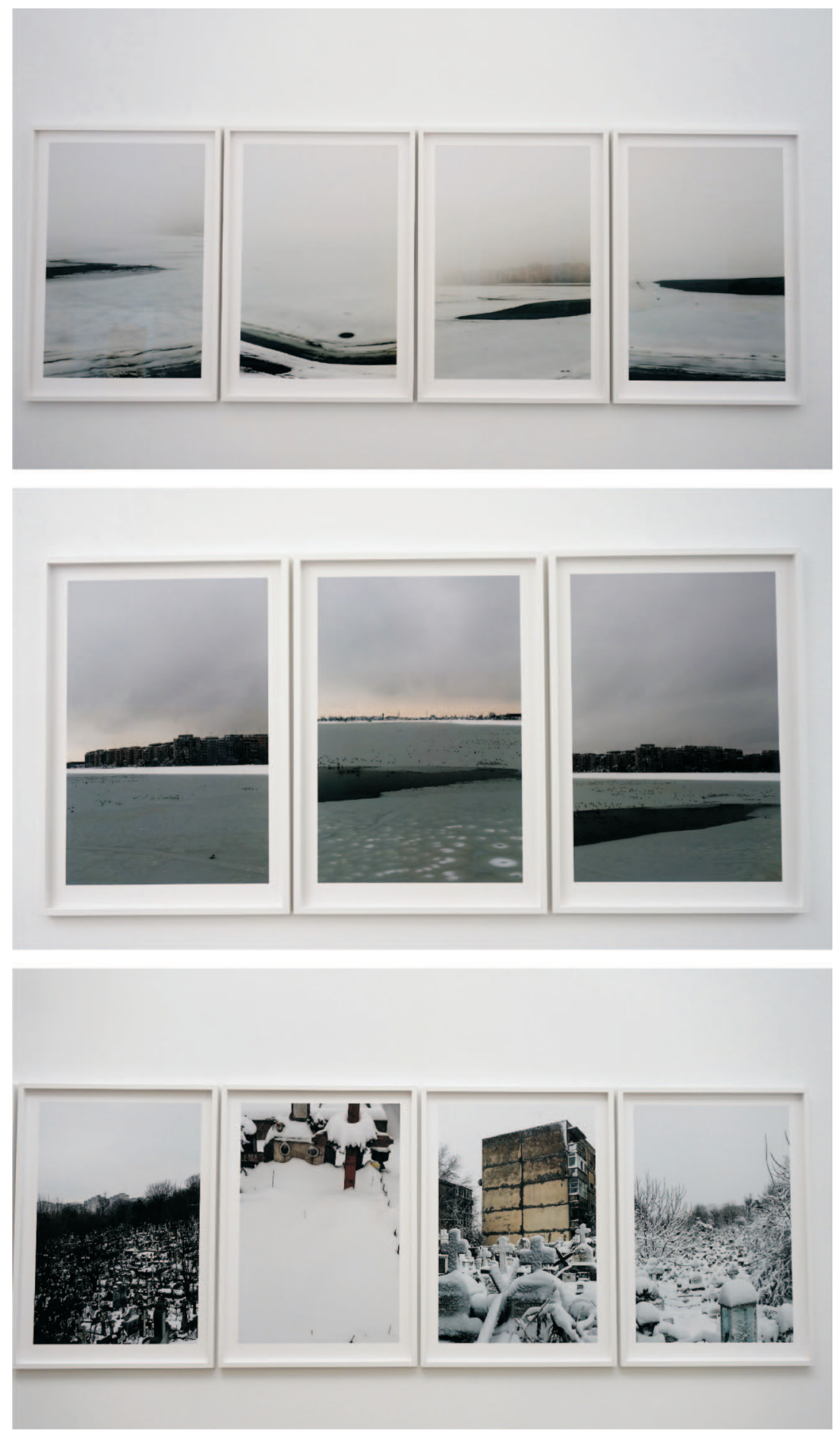